細胞癌の治療では通常，MRよりもCT検查のほうが簡 便で臨床的な有用性が高い. 肝細胞癌のCTではマル チスライスCTによるdynamic scanが望ましく, 単純, 動脈相, 門脈相，遅延相が撮影される。治療を行おう とする肝細胞癌は通常, 動脈相で濃染する腫瘍であり 放射線技師にとっても理解が容易である，撮影後，す ベての画像はPACSと3Dのワークステーションに送ら れ, 腫瘍の位置, 大きさ, 主たる動脈との位置関係, 門脈, 肝静脈との位置関係を画像化し, 大動脈とその 分枝の3D画像を作成する。

\section{2-2 術前検討会}

放射線科垁，看護師，放射線技師の出席する術前検 討会ではまず，担当の放射線科医から患者の現病歴の 紹介，治療方針の説明がある，CT画像で治療しょう とする腫演の大きさ, 位置が示され, 治療手技の終了 目標が示される。次に，放射線技師が3D画像を提示 し，主なる血管と腫場の関係が明らかにされる。これ らの情報をもとに議論が行われ，用意すべきカテーテ ル, 施行に際しての注意, 薬凨の準備などが看護師に も伝えられる。

\section{2-3 血管内治療の実施}

血管造影室に患者が入り，放射線科医，看護師が準 備を行い，その間に，放射線技師は向管の3D画像を 血管造影室のモ二タ上に表示する。操作室ではカテー テルが肝内に入り塞栓術が行われるときに必要な腫瘍 の位置, 血管との関係がよく理解できるように, 透視 イメージに近い観察方向で表示した画像を用意する。 カテーテルは腹腔動脈にかかりマイクロカテーテルが 肝内に進んだ状態になれば，血管造影室のモニ夕には 先ほど準備した画像に切り替わり, 透視画像と3D画 像により術者がマイクロカテーテルと腫瘍の位置関係 を正確に理解できるように援助する。Cア一ムが動き 透視の方向が変われば，この角度に従って3D画像も
変化させる。

最終的にマイクロカテーテルが目的とする位置に挿 入され，実際にここから塞栓物質を注入して問題がな いかを確認するために，CT-angiographyが撮影され る。このとき放射線技師は血管造影室に入り， CTの 準備を行い，放射線科医とともにCT撮影を行う。撮 影されたCTにより腫瘍が十分に塞栓されることを確 認する。この際, 3D画像を作成し, 塞栓される肝臓 の体積を画像上から推定する。

\section{2-4 治療終了後の画像作成}

治療終了後, 放射線科医は治療記録の作成とデー夕 整理を行い，放射線技師は治療記録に従ってこれを説 明するのに最も適した画像を選び, 所見ファイルに添 付する形でPACSに画像デー夕を送る。この際, 作成 した3D画像も治療結果を患者に説明する際に活用す るためにPACSに送り込む。

\section{3. 診療放射線技師に求めるもの}

以上に述べたように，血管内治療に際し放射線科医 が誩療放射線技師に求めるものは, 画像の専門家とし ての役割であり，この画像を処理や解析を行って，血 管内治療医としての放射線科医の業務を支援すること であると考える，従来の技師が行ってきた血管造影機 器の操作や撮影は, 現在の機器では放射線科医が単独 で十分操作できるようになっており，技師がこれを担 当しても利点はなく, 業務の効率化にはつながらな い. それよりも高度に専門化した画像を血管内治療の ために分かりやすく処理を行うことで，血管内治療の 精度を向上させるのに大きく貢献するものと確信して いる，血管内治療のような高度に専門化した医療には チーム医療が必要不可欠であ万う。このチームのなか で画像専門家として果たす責務は, これからもさらに 大きくなるものと考えている.

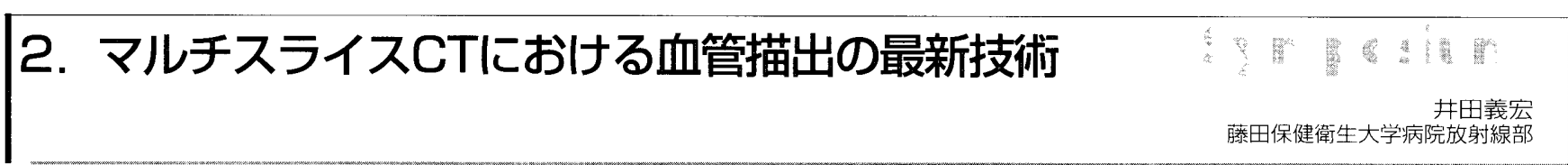

\section{はじめに}

X線CTを使用した血管描出では, 呼吸停止時間や造 影剤コントラストの確保のため短時間のスキャンが要 求さ机る. しかも，末梢血管描出に扔いては高い空間 分解能も要求され，さらに全身をめぐる血管に対して は広範囲にスキャンが必要となる。現在X線CTはマル
チスライスCTの時代を迎え，これらの要求に対して 十分な性能を手にすることが可能となった．現在もな 打更なる多列化や4DCTなどの技術革新が目覚まし く, 今回は現時点 (H. 14.4 現在)でのマルチスライス CTの性能とそれを生かした血管描出に関して述べ る。 


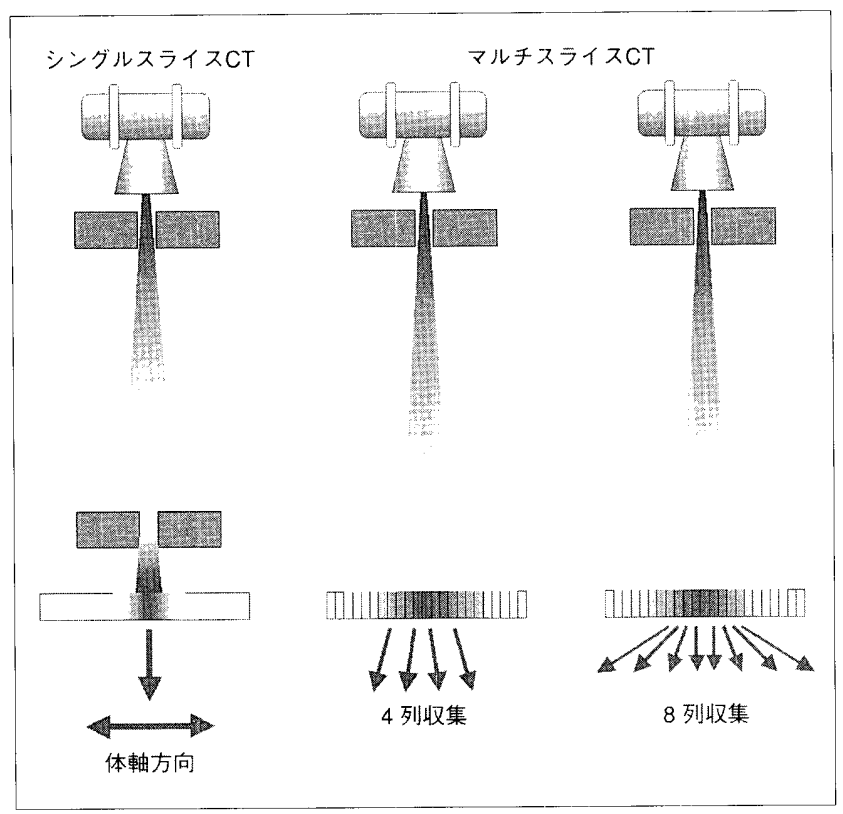

Fig. 1 シングルスライスCTとマルチスライスCTのデータ導 出

\section{1. マルチスライスCTとは}

マルチスライスCTとはX線管の回転方向と正父する 体軸厅向に対して，複数の検出器列を持ち，デー夕の 導出列により $2 ， 4 ， 8 ， 16$ 列のCTが製品化されている (Fig. 1).マルチスライスCTでヘリカルスキャンを行 うと，複数の㛟出器のデータタ乗り換えながら画像再 構成をするため，漫台速度(ヘリカルピッチ)を大きく しても画質劣化が少なく高速スキャンが可能となる.

\section{2. 撮影時間の短縮とスライスの薄層化}

ヘリカルスキャンの登場から現在までの装置の進歩 では，撮影時間が短縮され，スライス厚は薄層化して きた。例えば，X線管一検出器の回転速度は $1 \mathrm{~s} / \mathrm{r}$ から $0.5 \mathrm{~s} / \mathrm{r}$ 一(当院の研究機では $0.4 \mathrm{~s} / \mathrm{r}$ ) また最小スライス厚 も $0.5 \mathrm{~mm}$ が実用可能となった。

これらの技術により，横隔膜から坐骨までの範囲 (約 $500 \mathrm{~mm}$ ) を撮影する時間は， $2 \mathrm{~mm}$ スライスを用い て10秒以下でスキャン可能となり，同等の久キャン時 間で，肝臓などに範囲を限定した場合(約 $200 \mathrm{~mm})$ は $0.5 \mathrm{~mm}$ スライスでスキャン可能である(Fig. 2, 3).

\section{3. isotropic image}

短時間スキャンにより $0.5 \sim 1 \mathrm{~mm}$ 程度のスライス厚 を手に入れると，断層面方向と体軸方向の解像力がほ ぼ等しくなる。この意味するところは，1回スキャン したボリュームデータはどの方向加ら観察しても同等 の画質となるため，データの方向依存性もほとんどな くなる(Fig. 4, 5).

血管描出の立場で言い換えると，複雑な走行の血管

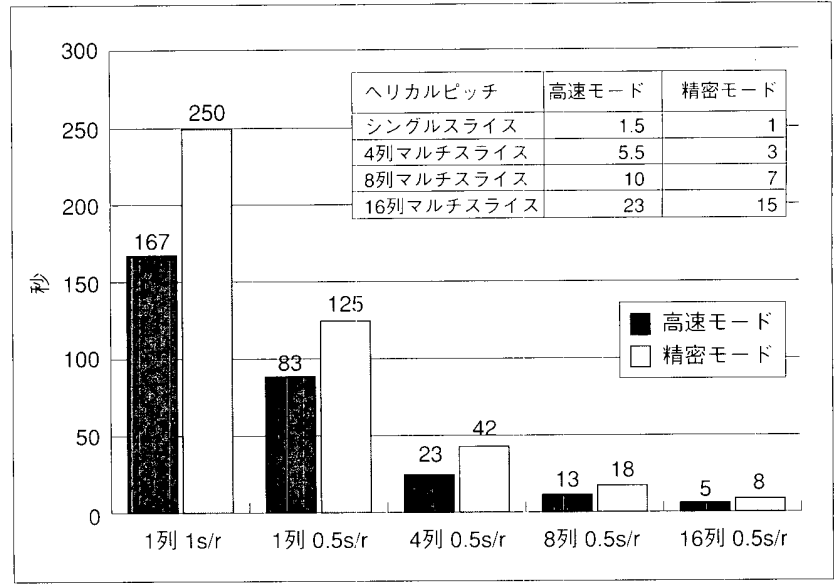

Fig. 2 高速化 $2 \mathrm{~mm}$ スライスで $500 \mathrm{~mm}$ の範囲を撮影した場 合のスキャン時間

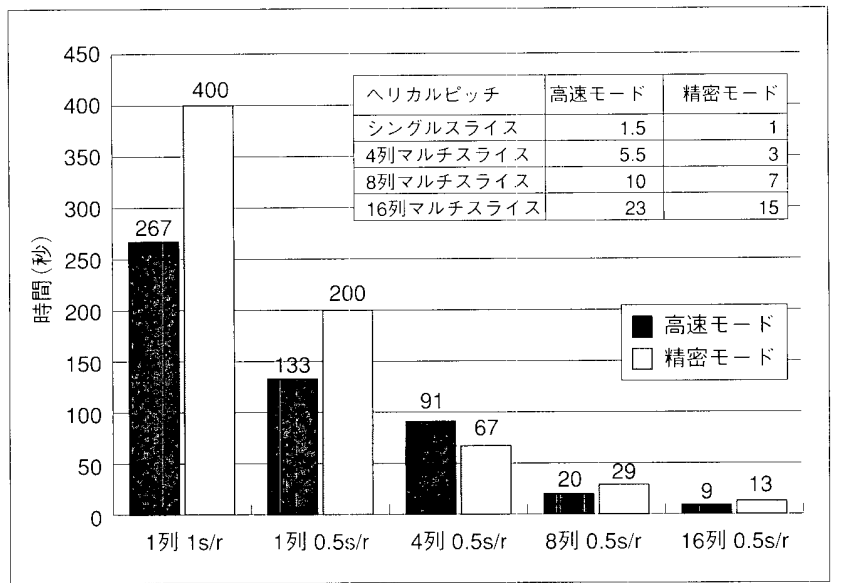

Fig. 3 高速化 $0.5 \mathrm{~mm}$ スライスで $200 \mathrm{~mm}$ の範囲を撮影した 場合のスキャン時間

をどのような正向から表示しても画筫は維持されるこ ととなる。

\section{4. 撮影時間の短縮に伴う造影剤の有効利用}

造影剤の使用方法も短時間スキャンにより変化す る。比較的太い血管の場合は造影剤量を減少さ也るこ とが可能となる(Fig. 6，7）。また微絒な血管を描出す る場合や，三次元妈理を行う場合には，㓮国の組織と のコントラストをより高く得るために造影戍注入速度 を上げ，造影剤量は減少させない。また正碓なスキャ ンタイミングを得るために造影剤モニタリング法(東 芝ではリアルプレップ)などのアプリケーションを積 極的に利用する。

\section{臨床例}

- 頭部AVM (Fig. 8) $135 \mathrm{kV} 260 \mathrm{~mA} \quad 0.5 \mathrm{~mm} \times 8$, HP5.8, $0.75 \mathrm{~s} / \mathrm{r}, 100 \mathrm{ml} 3 \mathrm{ml} / \mathrm{s}$, delay $2 \mathrm{ls}$ (real prep.) 徉来ウイリス動脈輪付近の範䍏を撮影していたスラ イス厚 $(0.5 \mathrm{~mm}) て ゙$ 脳全体のスキャンが可能となった。 


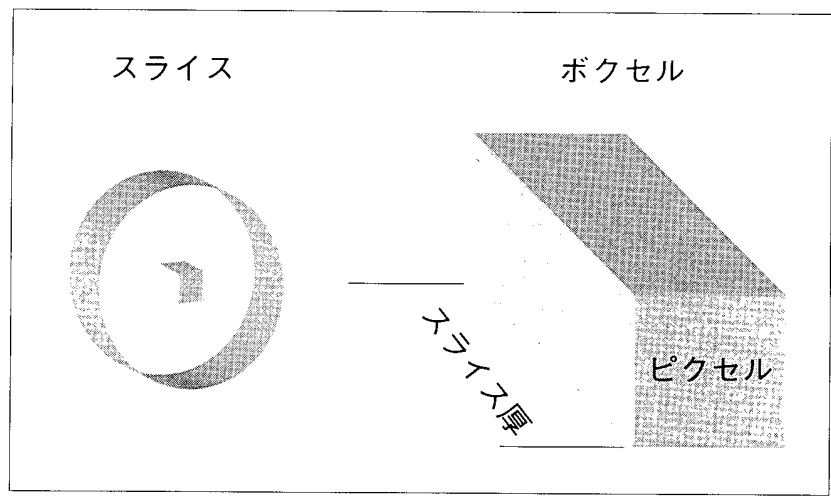

Fig. 4 CTのスライスとボクセル

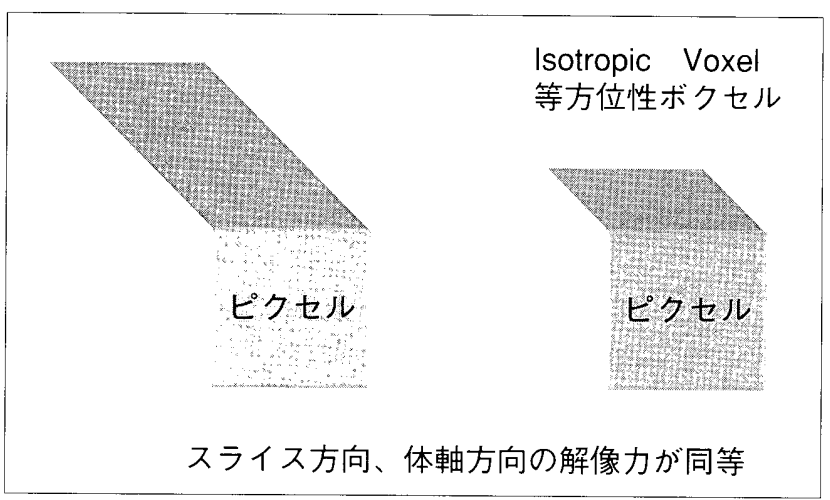

Fig. 5 isotropic image

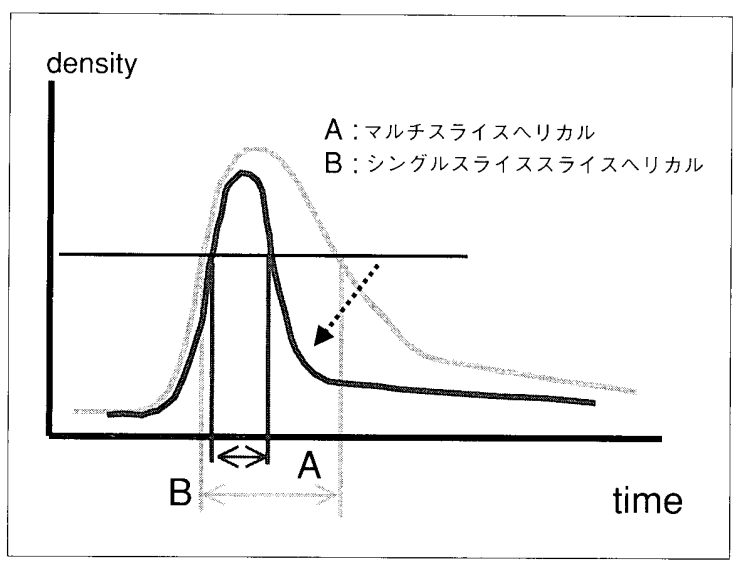

Fig. 6 造影剤量の減少

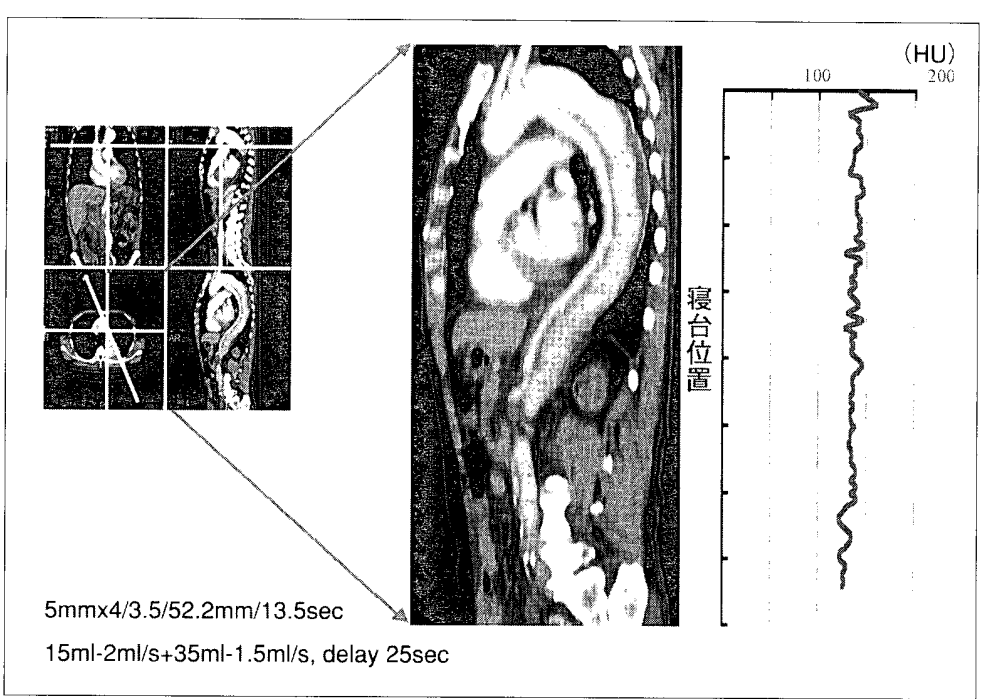

Fig. 7 大動脈解離 造影剂50cc

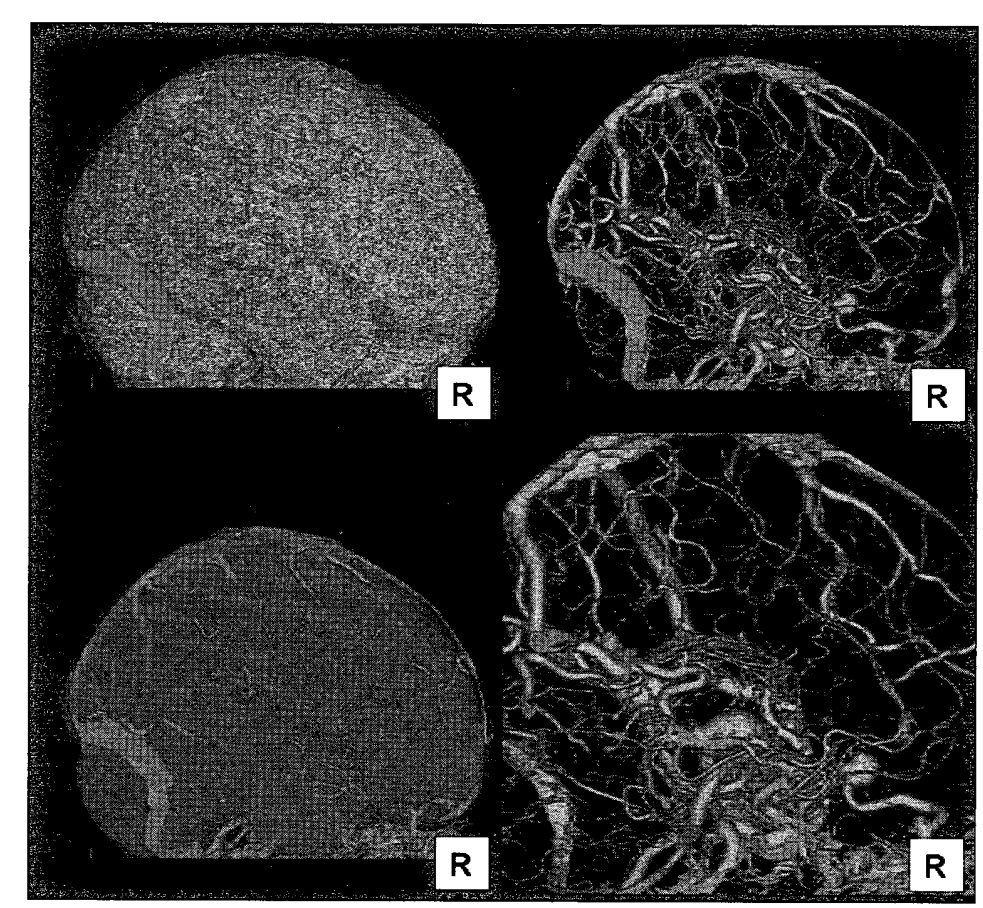

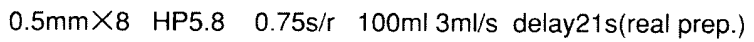

Fig. 8 AVM 


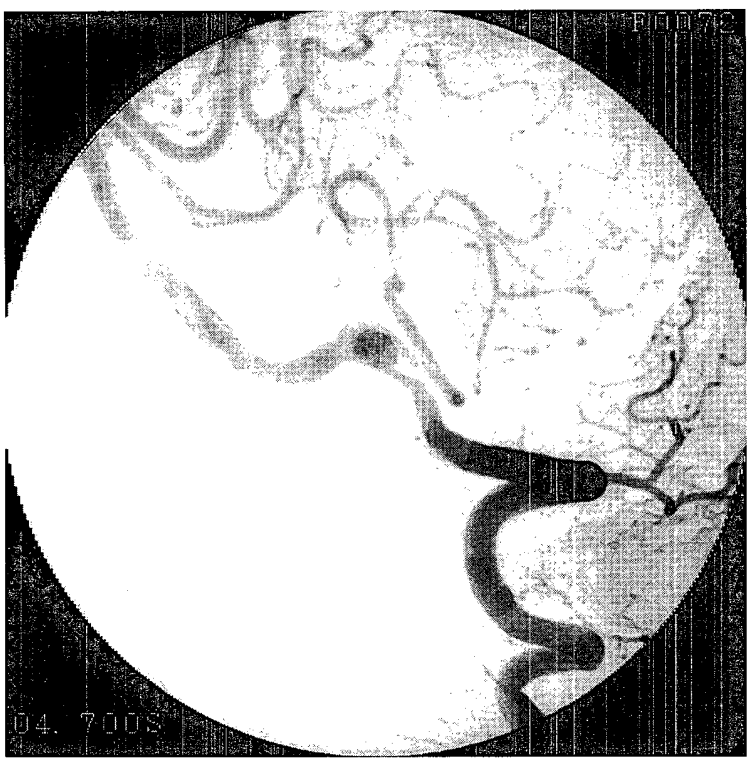

Fig. 9 Vertebral Artery Desection: Rt. VAG

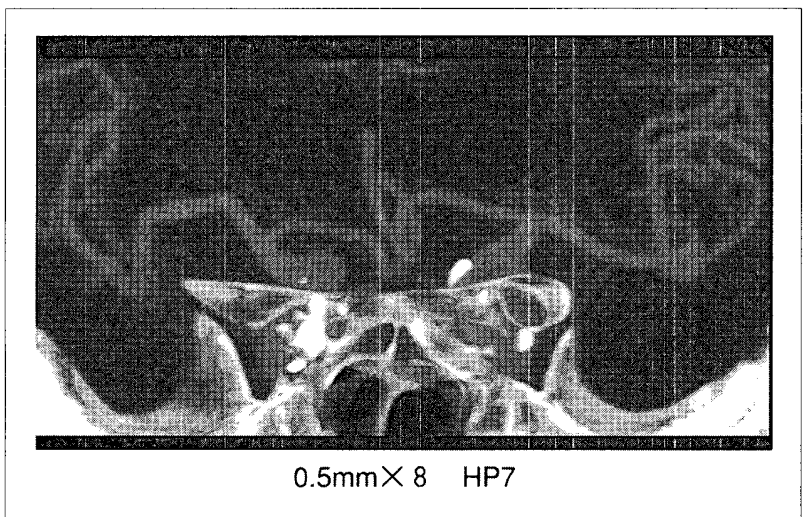

Fig. 11 穿通枝の描出

- 椎骨動脈解離 (Fig. 9， 10) $135 \mathrm{kV} 260 \mathrm{~mA}$

$0.5 \mathrm{~mm} \times 4, \mathrm{HP} 3.5,80 \mathrm{ml} 3 \mathrm{ml} / \mathrm{s}$ (real prep.)

カーブMPRで良好に描出されている。

・呀通枝の描出 (Fig. 11) $135 \mathrm{kV} 260 \mathrm{~mA}$

$0.5 \mathrm{~mm} \times 8$, HP7.0

MIP表示にて前後方向に観察した脳血管. 中大脳 動脈より上方に穿通枝(LSA)が確認できる.

- 大㟀管

スクリーニングで使用するスライス厚は4列装置で $3 \mathrm{~mm} ， 8$ 列の装置では $2 \mathrm{~mm}$ を使用している. $3 \mathrm{~mm}$ ス ライスでも解離腔の同定は可能である(Fig. 12１4）. 精密検查で $1 \mathrm{~mm}$ スライスでの撮影を行うと，全体 像の把握と局所の精密な観察が可能となる (Fig. $15)$.

・腹部血管 $(\mathrm{HCC}) \quad 1 \mathrm{~mm} \times 8, \mathrm{HP} 7.0$

三次元表面表示では血管の立体的走行が，MIP

では腫瘍に至る微細な血管の临出がなされてい

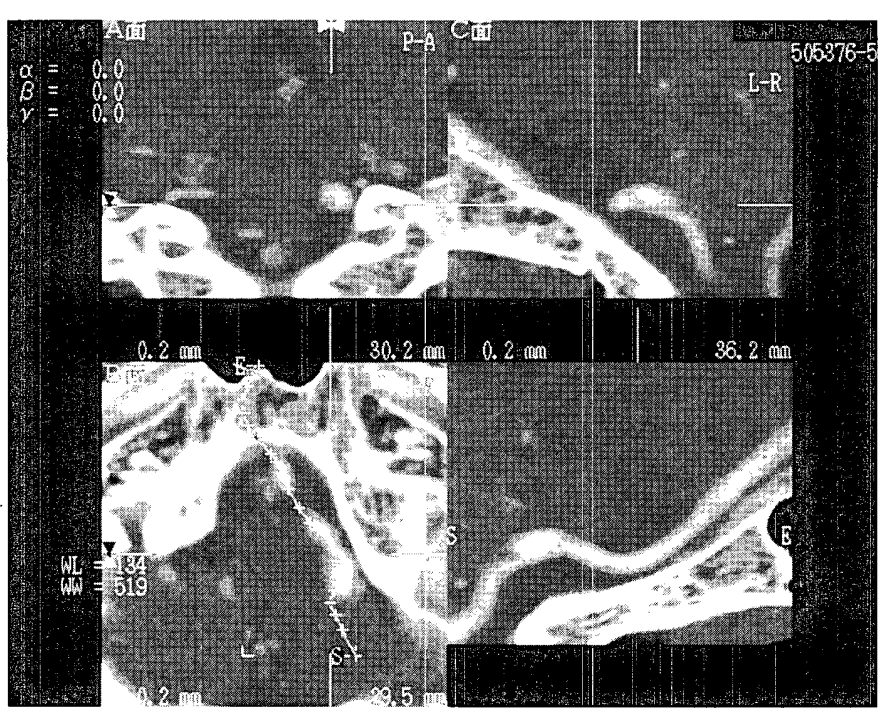

$0.75 \mathrm{~s} / 0.5 \mathrm{~mm} / 3.5 / 18 \mathrm{~s} / 135 \mathrm{kV} / 260 \mathrm{mAs} / 80 \mathrm{ml} /$ Prep

Fig. 10 Vertebral Artery Dissection: Rt. VA MPR

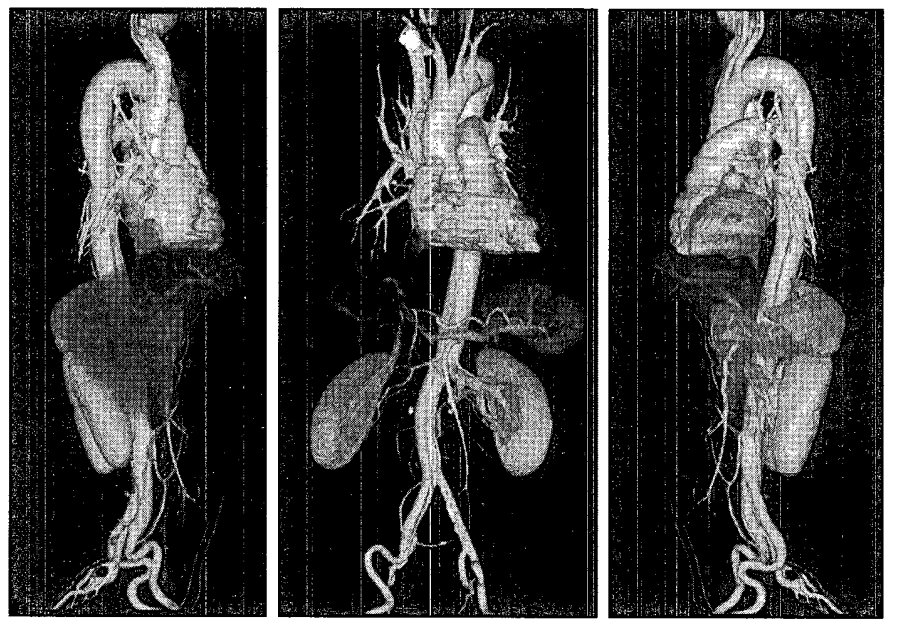

$55 \mathrm{M} / 3 \mathrm{~mm} / 3.5 / 567 \mathrm{~mm} / 27 \mathrm{sec} / 99(2) \mathrm{ml} / 25 \mathrm{~s}$

Fig. 12 大動脈解離

る(Fig. 16, 17).

\section{5. 心臟領域の血管描出}

マルチスライスCTで心臓領域の撮影をする場合， 心臓の拍動の影響を抑える必要がある。このため多列 化収集されたデー夕を高速・広範囲には利用せず，心 臓専用の収集法と再構成技術により, 時間(位相)分解 能の向上に利用する。したがって，寝台速度は速くで きないため, 全心臓を $0.5 \mathrm{~mm}$ スライスで撮影するには 16列以上のマルチスライスCTが必要である。

臨床例

- 陳旧性心筋梗塞 $0.5 \mathrm{~s} / \mathrm{rot}, 0.5 \mathrm{~mm} \times 8$, HP 2.2 (Fig. 18) 


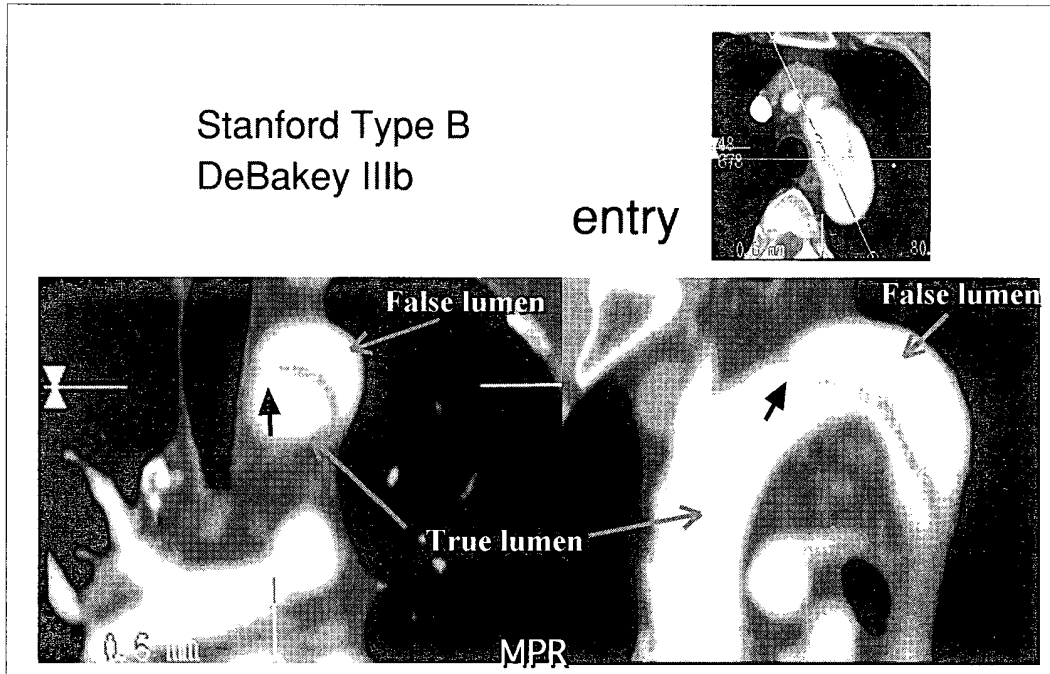

$55 \mathrm{M} / 3 \mathrm{~mm} / 3.5 / 570 \mathrm{~mm} / 27 \mathrm{sec} / 99(2) \mathrm{ml} / 25 \mathrm{~s}$

Fig. 13 大動脈解離 (Aortic Dissection)

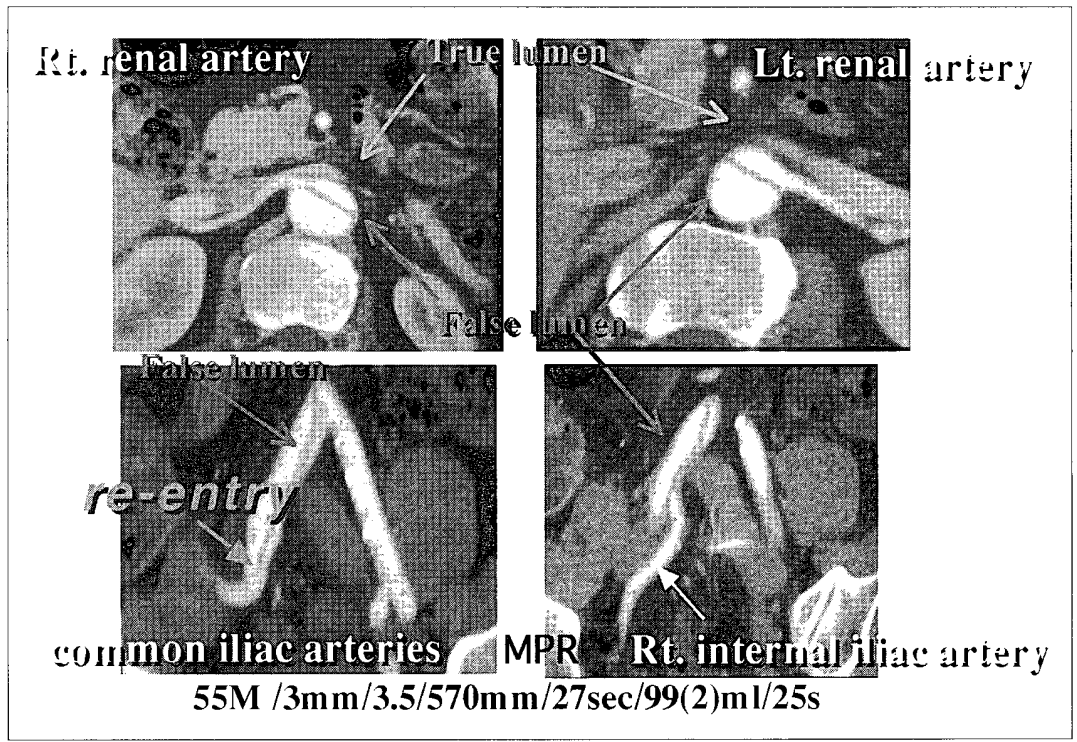

Fig. 14 大動脈解離

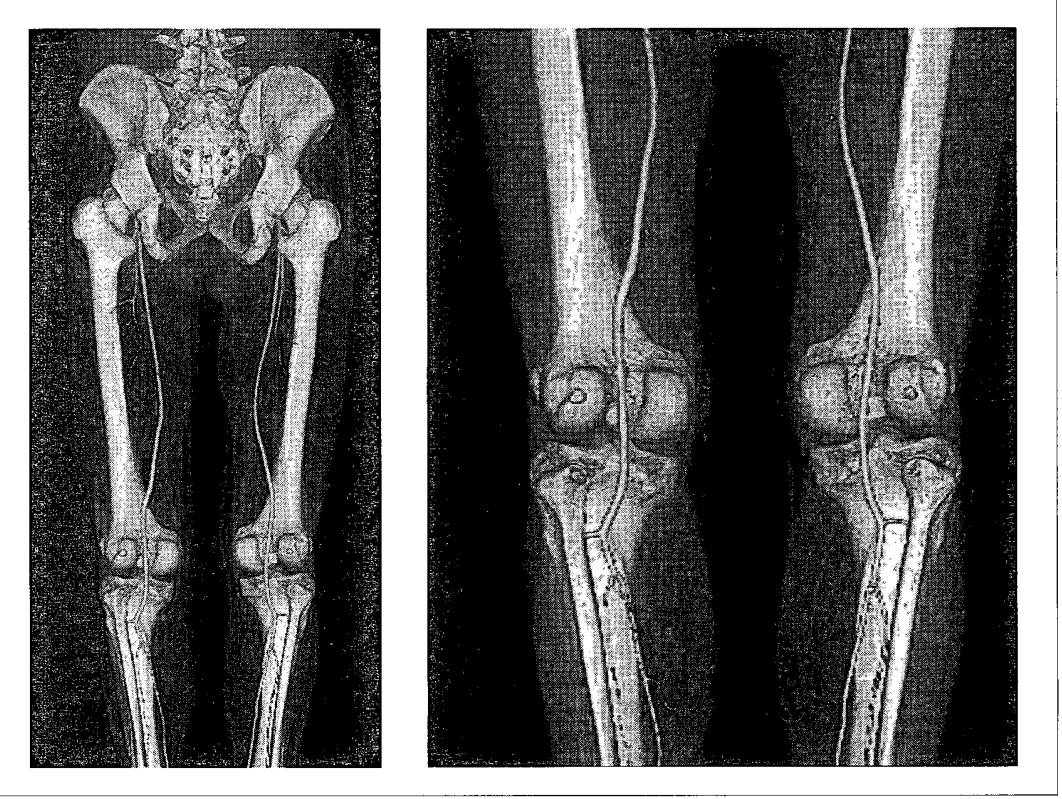

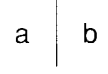

Fig. 15 ASO 8DAS

(a) 全体像

(b) 局所拡大 

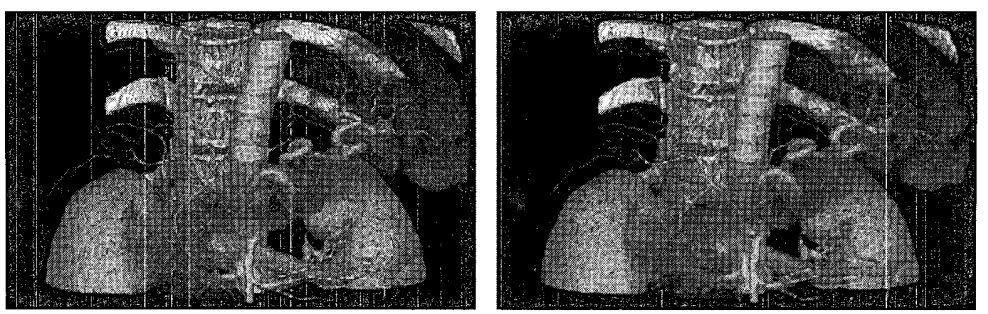

ステレオ

$1 \mathrm{~mm} \times 8 \quad \mathrm{HP} 7.0$

Fig. $16 \mathrm{HCC}$

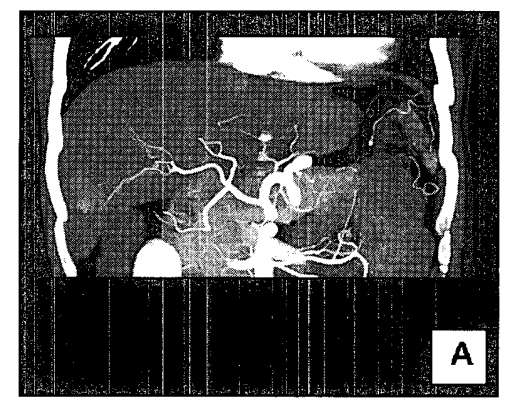

$1 \mathrm{~mm} \times 8$

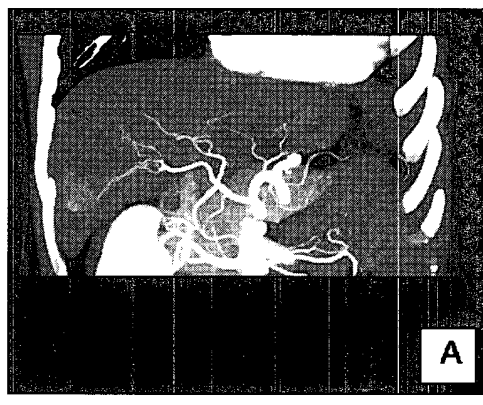

HP7.0 ステレオ

Fig. 17 HCC (MIP)

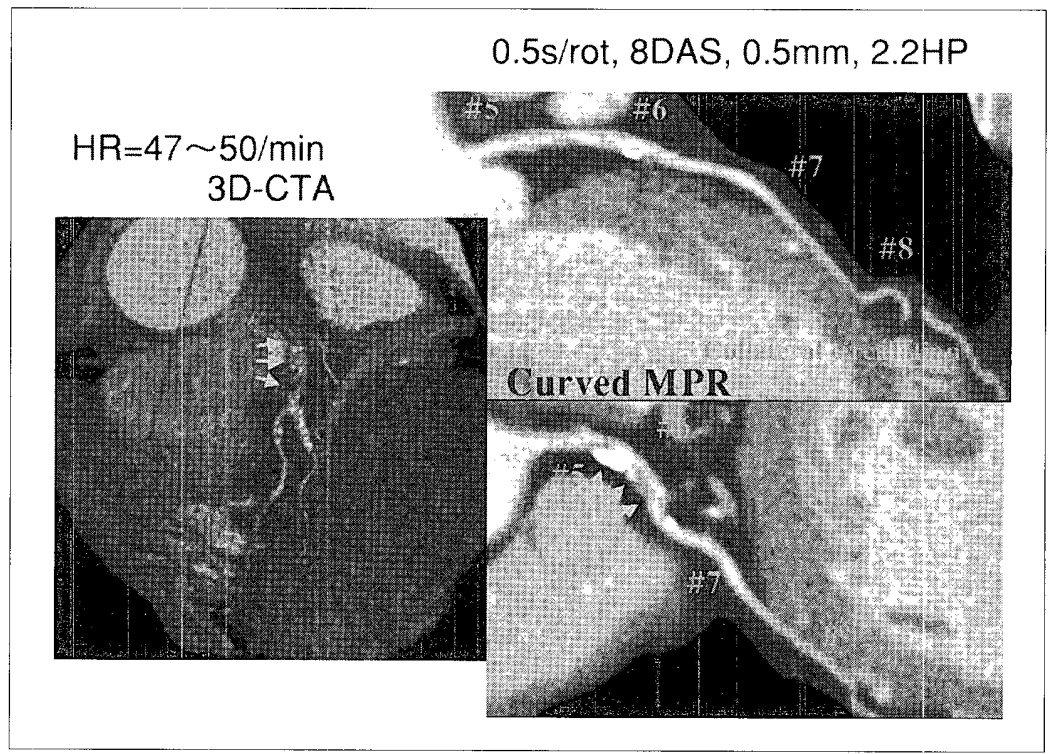

Fig. 18 陳旧性心筋梗塞(下壁)

Table 1 DSAに対する有用性

・1 回に撮影できる範囲が広い( $1 \mathrm{~m}$ 以上)

-目的臟器內の血管の三次元的走行や隣接臟器との関係も明瞭

-1 回の造影剂使用であらゆる方向からの観察が可能 (血管の重な りがない)
Table 2 MRIに対する有用性

・広範囲に感度ムラがない(均質性が良い)

・広範囲のボリュームデータの空間分解能が良い

・乱流の影響を受けない

•制約事項,禁忌事項が少ない(簡便)

・設備投資が少ない 


\section{6. マルチスライスCTにおける血管描出(3D- CTA)の有用性}

MRI，DSAなどと比較した場合，マルチスライス CTにおける血管描出にはさまざまな利点がある(Table 1，2）。とりわけ重要なことは，静脈注射で15分程度 の検査時間で終了することと，得られた画像が他のモ ダリティと比し，広範冊にわたり精密で均質な情報を 持っているということである。ただ，X線被曝や造 影剤の使用など考慮をすべき問題も抱えている。ま た，血管描出を目的とした検查では，8列以上のマル チスライスCTで1,000枚を超える画像データが発生す る.これらの画像処理に対し，現状ではワークステー ション (WS) の処理能力に大きな差があり，古いWSで は画像数の制限があり扱いきれないこともある。さら にこのような大容量データが十数秒のスキャンから発 生するので，ネットワークや画像保管に対して大きな 負担をかける(Table 3).
Table 3 マルチスライスCTによる3D-CTAの問題

·X線被曝
·造影剤を必要とする
·金属アーチファクトが避けられない
·骨の除去が困難 (WSに依存)
•マルチスライスの多列化により高密度で大量のデータが発生する
·高密度のデータから必要な情報の抽出 (画像処理)に時間がかかる
•ネットワークへの負担

\section{7. まとめ}

検査目的を明確にし，それぞれに適した検査法を選 択することが基本ではあるが，包括化医療をむかえた 現在，検査法には1回でどこまで多彩で高品質の情報 が含まれるかが問われてくる。マルチスライスCTの 高画質，簡便性などの有用性は，血管描出検査におい ても重要な選択肢となると考える。

\section{MRIにおける血管描出の最新技術・利用技術}

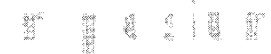 \\ 土橋俊男 日本医科大学付属病院放射線科}

\section{はじめに}

MRIは任意の断面を撮像できるため，大血管の走行 に合わせた撮像断面の設定が可能となる大きな特徽が ある。さらに，血管内腔を造影剤を用いることなく描 出可能であるとともに，撮像方法(pulse sequence)の 選択により血流を低信号あるいは高信号として描出可 能である。また，心電図に同期したシネMRIを応用す ることにより，血流動態の解析も可能である。最近で は， $\mathrm{T}$ 短絔型の造影偊を使用した高速撮像 (造影3DMRA : three-dimensional magnetic resonance angiography）が躯幹部を中心に広く臨床応用されてい $ろ^{1-3)}$.

これらのMRIの特徴に最新の撮像技術が加わり，短 時間で繰り返し撮像を行う time resolved MRAやMRDSA (magnetic resonance digital subtraction angiography) が臨床で使用されている。また，1回の造影剂の投与 で寝台を動かしながら広範囲を撮像するtable moving $\mathrm{MRA}^{4}$ ，5) や，目的血管に造影偊が到達した最適夕イミ ングで撮像が行える，タイミングモニタリング機能 (smart prep，visual prep $)^{6-8)}$ が実用化されている。造 影剤を使用せずに，pulse sequenceを工夫した非造影で の躯幹部・下肢MRAの実用化，マルチコイル高速撮像 法(parallel imaging) ${ }^{9}$, 10)を利用した撮像時間の短縮や 高分解能での撮像も話題となっている.
本シンポジウムでは，MRIにおける最新技術を用い た血管描出について，臨床画像を供覧しながらその有 用性および閭題点などについて述べた。

\section{MRAの撮像技術}

MRIに㧍ける血管描出は，血流を低信号に描出する spin echo(SE)法系列のpulse sequenceを用いた方法 と，血流を高信号に描出するgradient echo法系列の pulse sequenceを用いた方法がある(Fig. 1a，b).さら に，造影剤を使用しない血管描出技術と造影剂を使用 する血管描出技術が臨床で利用されている，今回のシ ンポジウムでは，血流を高信号に描出する撮像技術に 関して，造影剤を使用する方法と，造影剤を使用しな い方法に分けて，最新技術挹よびその利用技術につい て述べた。また，両者に利用可能な最新の撮像時間短 縮技術についても述べた。

\section{1-1 造影剤を使用しない血管描出技術}

造影剤を使用しない血管描出の代表的な技術は， time-of-flight (TOF) 法11)と㭔ばれる，RF pulseを受け ていない未励起のスピンがスライス面内に流入する効 果を利用する方法がある。TOF法は，造影剤を使用す ることなく，短時間で血管を高信号に描出可能であ り，頭部㧍よび頸部で広く利用されている。Fig. 1c， 